\title{
Poverty and Tourism: Strategies and Opportunities in Karimunjawa Island, Central Java
}

\author{
Budi Setiawan $^{1,2^{*}}$, R. Rijanta ${ }^{3}$, M. Baiquni ${ }^{4}$ \\ ${ }^{1}$ Post Graduate Programme, University of Gadjah Mada, Yogyakarta, Indonesia \\ ${ }^{2}$ Faculty of Social Science, University of Muhammadiyah Purworejo, Purworejo, Indonesia \\ ${ }^{3}$ Faculty of Geography, University of Gadjah Mada, Yogyakarta, Indonesia \\ ${ }^{4}$ Center for Tourism Studies, University of Gadjah Mada, Yogyakarta, Indonesia
}

\begin{abstract}
This article analyzes the strategies of Pro-Poor Tourism (PPT), i.e. the strategies to increase the benefits for poor people from tourism development. It explained the view that tourism, on a small or large scale, has a positive contribution to increased sources of income, creation of employment opportunities, and community development. However, there are still problems in developing the potentialities of the local labor force to contribute in the tourism sector. The development of tourism in Karimunjawa over the past ten years has undergone good progress, but the poverty rate in Karimunjawa is still fairly high. The problem of poverty is a complex one and is linked to a decrease in the main sources of earnings, i.e. fisheries and agriculture. The underlying concern is the fact that the growth of tourism in Karimunjawa has fostered the growth of resorts, hotels or the service sector owned and run by big investors, vis-à-vis the scant participation of the poor. The dominant types of job that the local community does are as employees or hired workers, and they are rarely involved directly in the planning and development of tourism, thereby restricting the potential role of the poor in the tourism sector in Karimunjawa. This study recommends strategies for the empowerment of the local community to enable them to make a considerable contribution to tourism in Karimunjawa in an endeavor to alleviate poverty and enhance the quality of human resources. One strategy recommended in this article is the adoption of a pro-poor policy through vocational training in tourism for the local community of Karimunjawa.
\end{abstract}

Keywords: Karimunjawa, poverty, Pro-Poor Tourism, tourism, vocational training.

\section{INTRODUCTION}

As the world's largest archipelagic nation, Indonesia has thousands of small islands with a number of endemic features of extremely typical and valuable diversity. Physically, the small islands comprise small-sized land area which has implications for the life of the people in these regions. Rijanta [1] explains that these small islands, besides having abundant potential marine resources, are extremely vulnerable to the volatile condition in the ecosystem, the environment, as well as the socio-cultural and political turbulence. They are subject to physical and social isolation [1] and the slow-moving demographic dynamic and accelerating migration. The condition of the regions which consist of small islands with limitations in transportation makes it difficult for the inhabitants to gain access to decent living, which enables them to survive.

\footnotetext{
${ }^{*}$ Correspondence address: Budi Setiawan

Email : budi_setiawan@mail.ugm.ac.id

Address : Faculty of Geography, University of Gadjah Mada, Sekip Utara Jalan Kaliurang, Bulaksumur, Yogyakarta
}

One of the major problems faced by the local people on the islets is poverty, which is a crucial issue for Indonesia as a maritime nation. The majority of the population that inhabit the islets earn their livelihood in the sea (as fishermen) and in agriculture (as farmer). Fishing and farming are two sectors in which the poor stand at a high employment figure $[2,3,4]$. The typical characteristics of the islets cause the farmers encounter obstacles in their process of production. Limitations in the availability of land, the supply of water, access to the market as well as the threat of climate change make it hard for the farming communities to develop. Fishing is a significant and important choice of occupation to increase earnings and maintain food security of the poor households with inadequate farmland [5]. On the other hand, the fishermen are under the increasing threat of climate change and the environment such as increased sea level, acidification of the sea, and the rise of the seawater [6,7]. The fishermen are also affected by economic policies, privatization of public facilities, deregulation of various economic activities and the market, as well as progressive liberalization of foreign trade $[8,9]$. 
The small islands with their fragile ecological condition, traditional socioeconomic structure, limited resources and undeveloped infrastructure $[9,10]$ require alternatives of economic development, one of which is tourism. The tourism industry is a sector which is considered labor intensive and offers significant potential for sustainable growth in developing countries that may have limited growth options $[12,13,14]$. However, tourism can be useful if it is devised and integrated into the local system [15] especially when the promotion and development of tourism are done in partnership involving the government, NGO (Non Governmental Organization) and the local community. In the past decade, the idea that the growth of tourism can contribute sufficiently to poverty alleviation has greatly encouraged the emergence of a policy in tourism development with a pro-poor tourism approach.

The term Pro-Poor Tourism (PPT) was introduced in 1999 and implemented in Britain for economic development by putting tourism as a sector that could contribute to poverty alleviation. PPT is not aimed at expanding the scale of tourism but is intended to open up opportunities for the poor in tourism at all levels and scales of operation $[16,17]$.

The strategies of PPT development are to improve economic benefits, to open up business opportunities for the poor, and to raise the people's collective incomes, and to improve noneconomic benefits, and build up capabilities, set up training and practice; to reduce the environmental impact of tourism on the poor, to cope with the socio-cultural effect of tourism. The PPT approach is very interesting in analysis of livelihood $[18,19]$. This analysis is important if tourism will be used to contribute to the welfare of the poor. In order to maximize the contribution of households and to avoid the poor households' dependence, tourism can be used to diversify the people's means of livelihood.

In the context of tourism development, local participation is important, not only to fill the demand for manpower but also to provide services that encourage more tourists to visit through the local people's attitude and way of life. Tourism development depends not only on natural resources and the attraction of promotion campaigns but also on the willingness of locals to welcome tourists and give them satisfactory services. The locals' preparedness is a moral support for the tourism sector and it directly reflects their readiness to participate in the tourism industry.

This article provides a contribution to a discussion of the points above by depicting the impact of tourism development on the most popular holiday destination in Central Java, i.e. Karimunjawa Island, which also includes the process of developing the holiday destinations on the island, the contribution of the local community, and poverty alleviation. Our discussion is divided into three parts. The first part begins with a brief description of issues in relation to poverty on the island in the context of the dynamic of tourism on the island at the present time, followed by a depiction of the impact of tourism on the life of the local people. The third part offers an analysis of the findings of this research.

\section{MATERIAL AND METHOD Study Area}

This study is a descriptive qualitative research. This approach is used to reveal the implementation and dynamic of Pro-Poor Tourism in the development of tourism in Karimunjawa. The research was conducted in Karimunjawa Sub-district, which is one of the sub districts in Jepara Regency, Central Java. Karimunjawa is one of the areas that have been designated as a pre-eminent holiday destination in Central Java besides Borobudur Temple, Dieng, and Sangiran. Geographically Karimunjawa Island is located 45 nautical miles or about $83 \mathrm{~km}$ northwest of Jepara, at a height of 0-605 $\mathrm{m}$ above sealevel, at $5^{\circ} 40^{\prime} 39^{\prime \prime}-5^{\circ} 55^{\prime} 00^{\prime \prime}$ and $100^{\circ} 31^{\prime} 15^{\prime \prime}$ East Longitude (Fig. 1), with an area of 169,800 ha consisting of a land area of 7,120 ha and $a$ marine area of 162,680 ha [20].

\section{Data Collection}

The primary data were gathered through indepth interviews to several key persons who selected by purposive and snowball sampling method. The key persons represent the most capable person in their sub-district who could give some important data and information as individual, household and community member. Respondents comprise six informants selected from the pre-welfare community, tour operators, and travel agencies, community elders/public figures, village authorities, and the subdistrict head. Primary data also obtained through observation and documentation. 


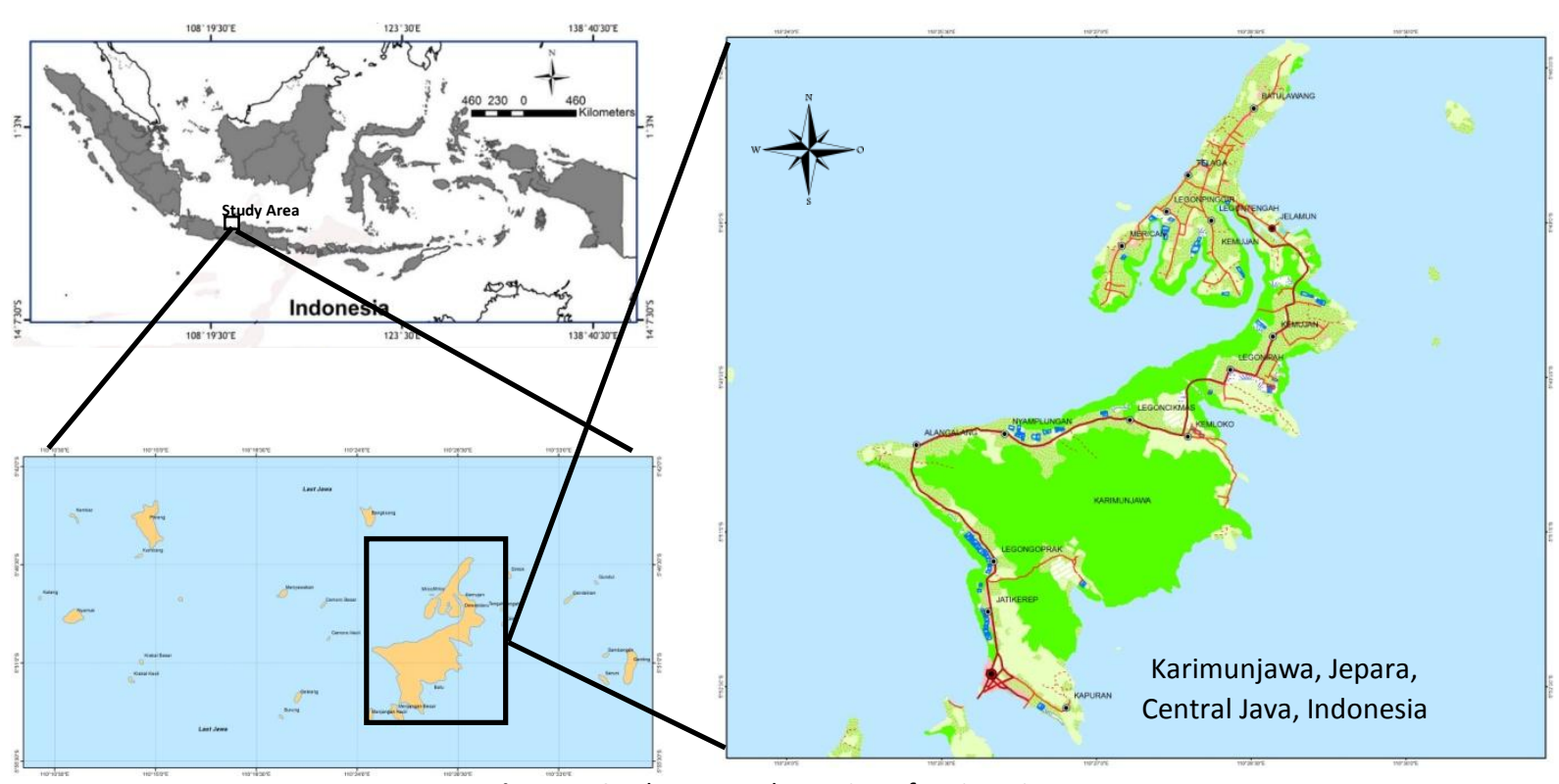

Figure 1. Study Area and Location of Karimunjawa

Secondary data were from official documents and literature relating to the research questions. The secondary data are social economic level, demographics, and tourist visits. Data collected by library research to gather data from a number of references related to spatial planning, demography, tourism, etc.

\section{Data Analysis Method}

As a qualitative research, this research adopted a logistic approach to analyze findings and data, and draw a conclusion at the end. Data collection and the process of analysis were done simultaneously. Data analysis used in this research consisted of three activities, namely 1 ) Data Reduction by summarizing, selecting, and focusing on important matters, finding the theme and pattern. In this case, the implementation of the pro-poor tourism approach was investigated. 2) Data Display: the compilation phase and the presentation of information to be used in the depiction of the study results. 3) Drawing Conclusion in which a preliminary tentative conclusion was drawn; this would be modified if strong evidence was lacked. It was done to support the next phase of data collection. Valid evidence would support the suggestion and consistent conclusion, which would be put forward as a credible conclusion.

\section{RESULT AND DISCUSSION \\ Poverty in Karimunjawa}

Karimunjawa Sub-district administratively consists of four villages, i.e. Karimunjawa, Kemujan, Parang, and Nyamuk. All the villages in the subdistrict are typologically coastal area at an altitude of less than $500 \mathrm{~m}$. The center of administration of Karimunjawa Sub-district is located on Karimunjawa Island, which is $\mathbf{4 0}$ miles from Kartini seaport in Jepara, and can be reached by boarding Bahari Express Sailing Ship, which takes about two hours or less than four hours by speedboat.

In 2014 Karimunjawa Sub-district had a population of 9,016 consisting of 4,547 men and 4,469 women. It was the most sparsely populated subdistrict in Jepara Regency $(0.78 \%)$, which comprised 2,621 households so that on average a household had 2-4 members. Karimunjawa Village was the most densely populated, i.e. 4,557 or $50.54 \%$ of the total population in the subdistrict, whereas Nyamuk Village was the most sparsely populated, i.e. 551 or $6.11 \%$.

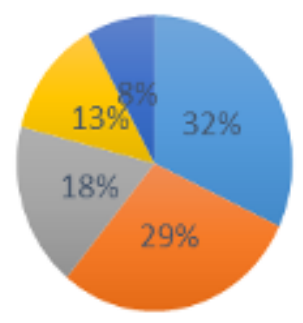

\section{aPre-Welfare w Welfare I $\quad$ Welfare II - Welfare III -Welfare Plus}

Figure 2. Welfare Levels of the Karimunjawa Inhabitants 
According to a report by the BPS (Central Statistics Bureau) in 2016 [21], the welfare level of Karimunjawa Sub-district was low: $32 \%$ belonged to the category of pre-welfare households, and $27 \%$ to the category of welfare 1 households (Fig. 2).

The pre-welfare householders in Karimunjawa Sub-district are scattered in four villages, in which Parang Village has the greatest number of pre-welfare households, i.e. $39 \%$ of the total population of the village, followed by Nyamuk, Karimunjawa, and Kemujan villages (Table 1). From the total percentage of pre-welfare inhabitants in Karimunjawa Sub-district, Karimunjawa Village has the highest percentage of $32 \%$ followed by Kemujan Village with $30 \%$.

Table 1. Total of Households According to Welfare Status

\begin{tabular}{lcccc}
\hline \multirow{2}{*}{ Welfare Status } & \multicolumn{4}{c}{ Percentage (\%) } \\
\cline { 2 - 5 } & Karimun & Kemujan & Parang & Nyamuk \\
\hline Pre-Welfare & 32 & 30 & 39 & 34 \\
Welfare I & 27 & 33 & 31 & 29 \\
Welfare II & 17 & 21 & 15 & 18 \\
Welfare III & 14 & 11 & 8 & 10 \\
Welfare Plus & 10 & 5 & 7 & 7 \\
\hline Total & $\mathbf{1 0 0}$ & $\mathbf{1 0 0}$ & $\mathbf{1 0 0}$ & $\mathbf{1 0 0}$ \\
\hline
\end{tabular}

Source: Karimunjawa Sub-district in Figures [22]

The poor and extremely poor households in Karimunjawa subdistrict are 1,803 in number with the total members of 7,212 (assuming four members per household). Based on observation in the field, poverty on this island is caused by the low earnings of the farmers and fishermen; the biggest communities on Karimunjawa Island. This condition is due to their inability to maximize the access to the local potentialities. In many studies of farmers and fishermen as the group most vulnerable to poverty $[2,3,4]$.

It is increasingly difficult for the traditional fisherman in Karimunjawa to obtain a maximum catch of fish, and they fail to compete with other fishermen who have modern equipment. Their catches began to diminish even more when large ships came to operate there. These ships are furnished with cold storage, sophisticated tools for catching fish, a fish finder, a radio for communication, and a magnetic compass. The fish caught by the traditional fishermen are merely sufficient to meet their basic needs, especially food. Furthermore, according to a report on the zonation of the National Park of Karimunjawa in 2012, it is found that the biomass of rockfish and its abundance monitored from 2004 to 2009 was generally diminishing in all zones. During 2007-2009 there was a significant decline of the biomass of rockfish, i.e. 25.55 percent, from $480.25 \mathrm{~kg} \cdot \mathrm{ha}^{-1}$ in 2005 to 200.30 $\mathrm{kg} . \mathrm{ha}^{-1}$ in 2009 . The fisherman have been aware of this condition, as expressed by our informant MD (52) who said that "if the fishermen's current amount of catch was the same as that ten years ago, the fishermen would be all well-off by now".

The subsistent farmers in Karimunjawa are not capable of introducing innovations to increase productivity and maximize land management of non-irrigated and wet rice fields. Not much technology has been developed in the agricultural and animal husbandry sectors. Limitations in the availability of land and water as well as the dynamic climate change make it hard for the agricultural sector to develop. The production levels of agriculture and animal husbandry in Karimunjawa have continued to be on the decline from year to year. According to informants MN (54) and AM (44), the people's interest in cultivating land and being engaged in breeding farm animals has decreased, and they prefer to buy foodstuffs in the market, where the commodities such as rice, cassava, and bananas are brought in from outside the island. They say that the soil in Karimunjawa is not suitable for agriculture: they tried growing corn and bananas but the yields were poor. They once even tried growing various kinds of prime seed corn and bananas but to no avail.

The high poverty rate in Karimunjawa Subdistrict runs parallel with the data on the low levels of education. Most of the people there are Primary School leavers (47.98\%), and in fact there are a considerable number of those who did not finish Primary School education, i.e. $32.67 \%$ (Table 2). Considering the high percentage of the productive age group, the quality of human resources in the subdistrict is arguably low.

Table 2. Levels of Education

\begin{tabular}{lc}
\hline \multicolumn{1}{c}{ Level of Education } & Percentage (\%) \\
\hline None & 1.58 \\
Primary School but dropped out & 32.67 \\
Primary School & 47.98 \\
Junior Secondary School & 8.15 \\
Senior Secondary School & 8.15 \\
Diploma 1-D3 & 0.04 \\
Diploma 2 & 0.44 \\
Diploma 3 & 0.99 \\
\hline Total & 100.00 \\
\hline
\end{tabular}

Source: Karimunjawa Sub-district in figures [22]

Most of the people in Karimunjawa work in the informal sector, i.e. $88.56 \%$ with the highest percentage as fishermen (59.53\%), and as 
farmers (19.32\%) whereas others work as farm laborers, construction workers, artisans/ craftsmen, shopkeepers/tradesmen, breeders and mechanics. As a matter of fact, it is very difficult to distinguish between the communities of fishermen and farmers, and classify them into two groups in terms of means of livelihood because in reality, many of them are engaged in both spheres. At certain times they cultivate the fields, but at other times they also go fishing or manage inland fisheries.

\section{Tourism Growth and Its Impact on Karimunjawa}

One of the potential spheres for economic development on the island is tourism, which is the largest industry in the world and has been an integral component of the strategy for economic development in various countries. Tourism has the potential for yielding foreign exchange, drawing international investments, increasing tax revenues, and creating new opportunities for employment. Visits by domestics and foreign tourists to Karimunjawa Island have significantly increased since 2007. In 2015 there were 7,579 foreign visitors to the island, and 84,536 domestic visitors, and the number continued to increase in comparison with the numbers in the preceding years [22]. Visits by domestic and foreign tourists increased in frequency as much as $158 \%$ and $166 \%$ compared with visits in 2007 (Fig. 3). This shows that there is considerable potential for tourism development in Karimunjawa. This potential is balanced by the opening of a ferryboat crossing in Kendal seaport in addition to the one in Jepara seaport.

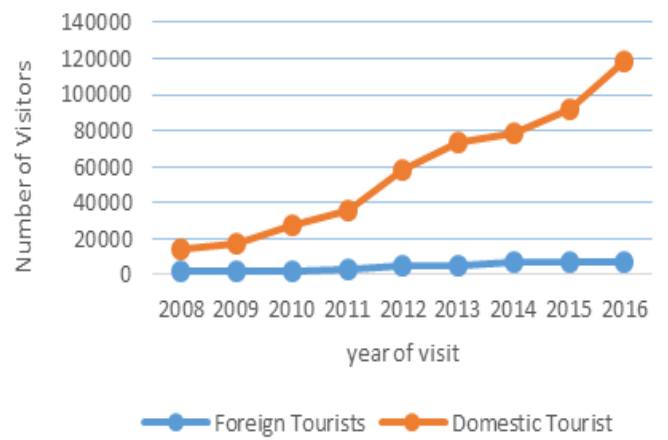

Figure 3. Graphic of visits to Karimunjawa [23]

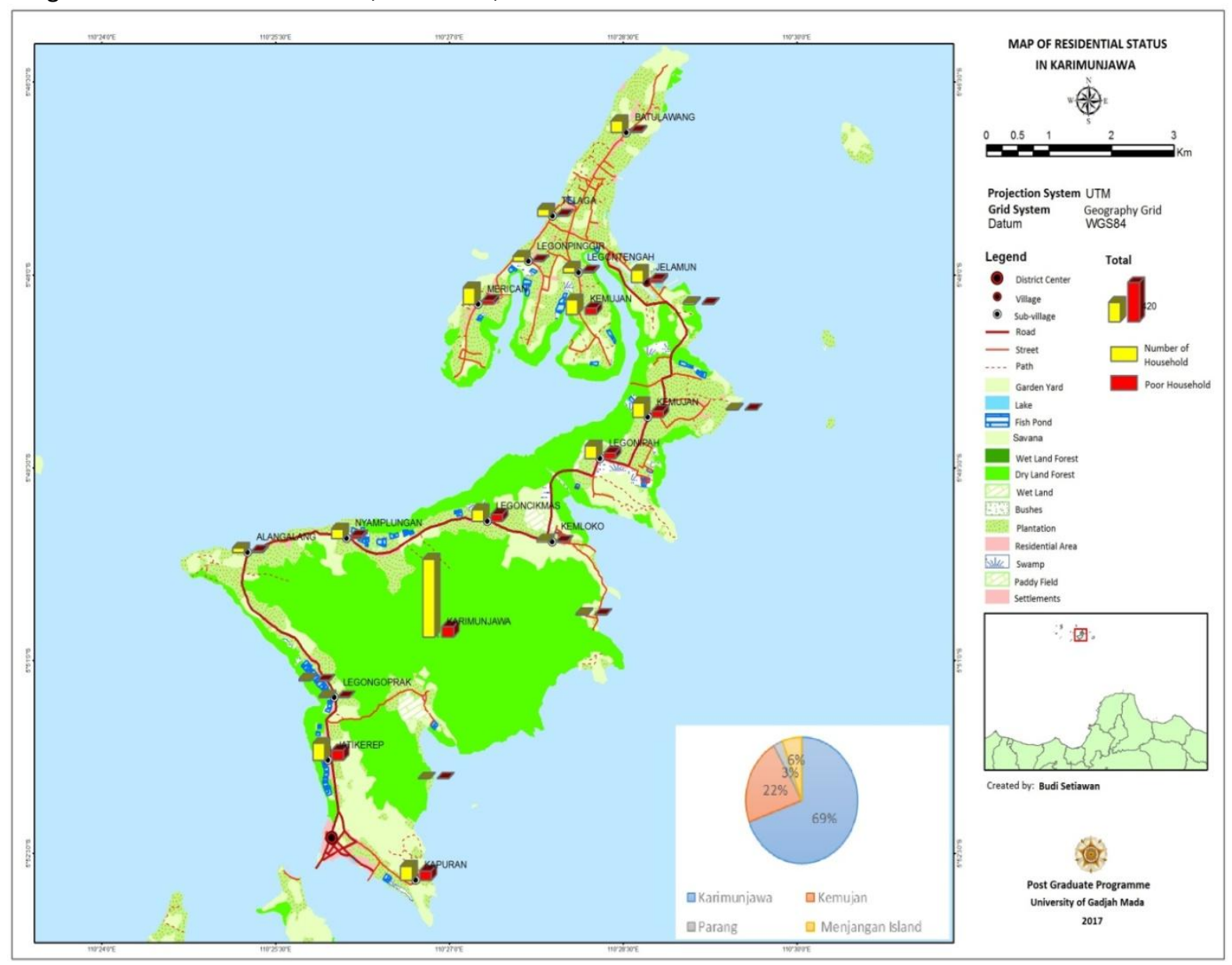

Figure 4. Distribution of Destinations on Karimunjawa 
There are about 38 destinations in Karimunjawa which appeal to both domestic and foreign tourists. The frequently visited destinations are the Shark Pond, Snorkelling on Menjangan Island, and a few coasts (such as Barakuda, Batu Topeng, Nirwana, Ujung Gelam, Kemloko, Batu Putih, Batu Lawang) and track events in a mangrove forest. Karimunjawa offers, in addition to nature tourism, religiously oriented tourism, visits to the cemeteries of past pious leaders (e.g. Sunan Nyamplungan), Sayyid Kambang, and Sayyid Abdullah). Annual events also serve as tourist attractions Barikan and Sail Karimunjawa. Karimunjawa village is the most frequently visited destination, i.e. 69\% (Fig. 4).

Tourism development in Karimunjawa Village is more noticeable than that in Kemujan Village. This is because, besides being a village with a predominance of tourist destinations, Karimunjawa is a place of entry for tourists on Karimunjawa Pier. This condition has encouraged the construction of facilities and infrastructure for tourists in the village. Within the period 20112015 the growth of hotels, resorts, and homestay accommodation was fast: an increase of $40 \%$ for hotels and resorts, and $56 \%$ for homestay accommodation (Fig. 5).

As illustrations of the condition of hotel affairs in Karimunjawa, the tourists' length of stay was $45.23 \%$ in 2014 and $53.53 \%$ in 2015 . On average, they stayed for 2.64 days: domestic tourists stayed 2.43 days and foreign tourists 4.73 days.

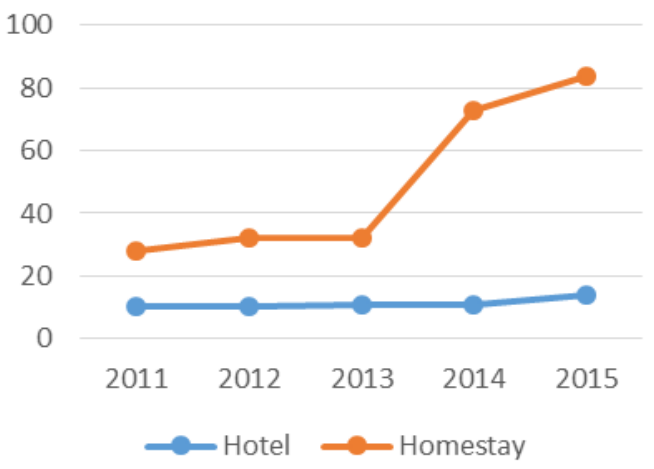

Figure 5. Number of Hotels and Homestay Lodgings in Karimunjawa

The growth of tourism in Karimunjawa gave rise to considerable business potential as it induced big investors to invest their money (Fig. 6). Since then, land prices in Karimunjawa have soared. Everybody knows that unused, uncultivated land in Karimunjawa is a potential gold-mine that should be exploited. There is a tendency among the people who own land to sell it and benefit from this momentum (Fig. 7).

\section{Economic Access to Tourism for the Local Community}

Karimunjawa has great potential to become a pre-eminent tourist destination. Tourism develops promisingly with the availability of facilities and infrastructure that supports the potential but of course it requires human resources to manage them. The proliferation of hotels, resorts, homestay accommodation, sales of souvenirs, transportation services, and tour guides has created extensive job opportunities for the communities in and outside Karimunjawa.

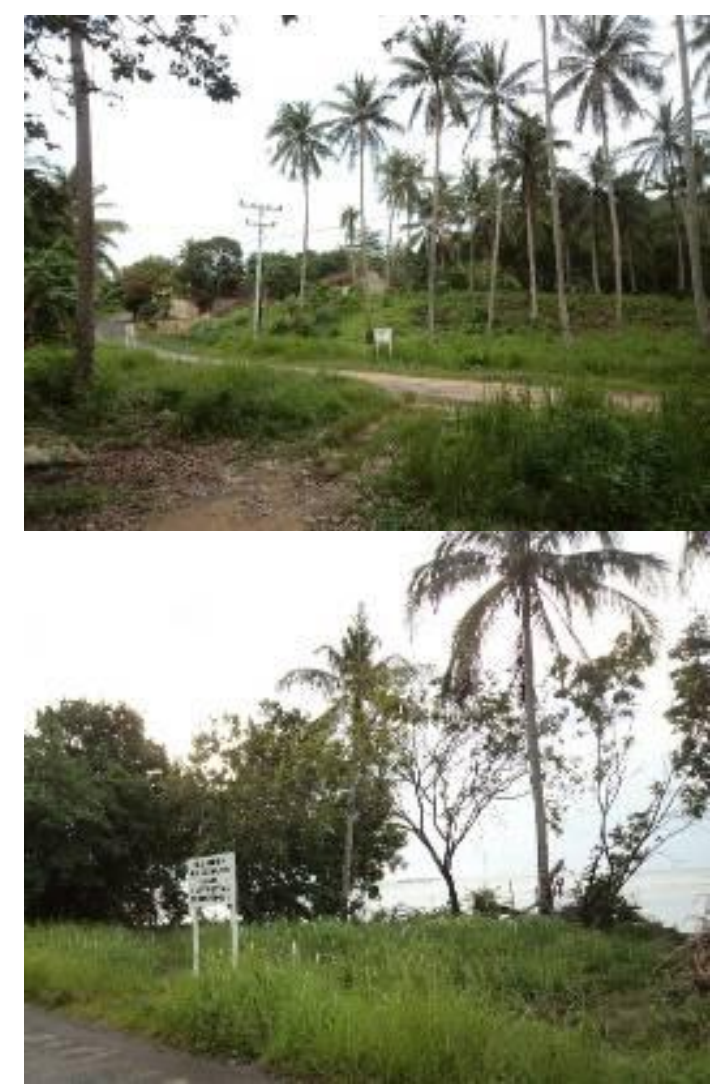

Figure 6. Possession of Land by Investors

The condition of tourism development in Karimunjawa has been benefited by the people there, including the fishermen. The opportunities for increased earnings through tourism are widely open. The declining trend of catches of fish causes the fishermen to find alternative jobs. The majority of fishermen who participate in tourism-related activities have expressed their reasons to take options.

The tourism sector has become increasingly attractive to the people of Karimunjawa so that many of them have switched their interest to this 
sector as an additional means of livelihood. The kinds of economic activity that they do are making souvenirs, hiring out boats, guiding tourists, and letting out modest homestay accommodation, but these are casual work, not their main occupations depending on the number of visitors or holiday-makers and the climatic conditions in Karimunjawa.
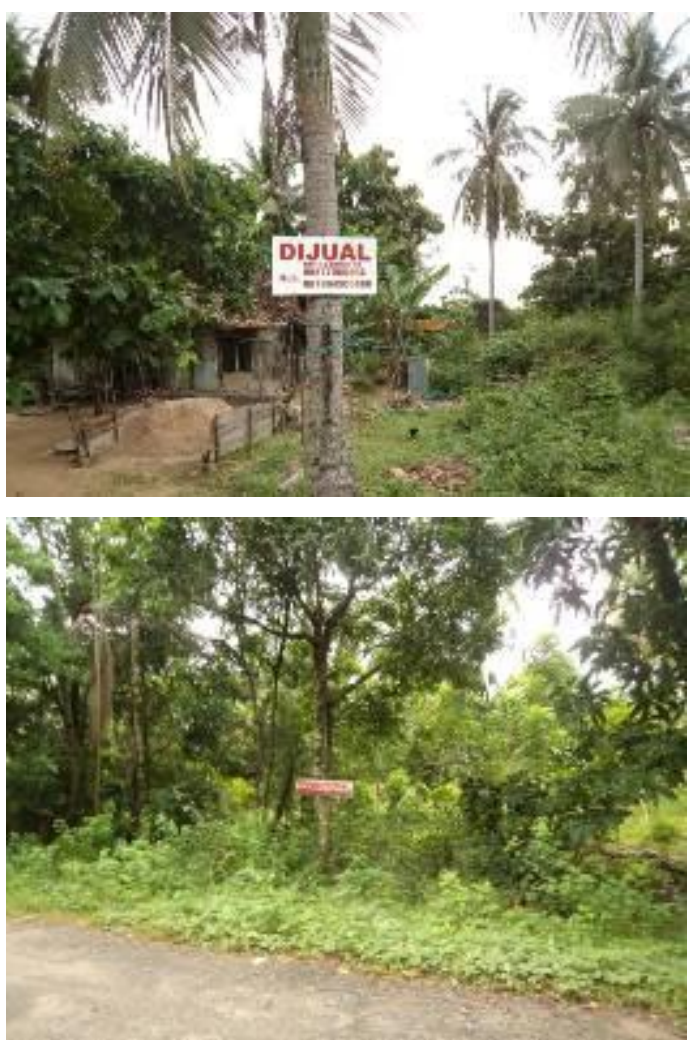

Figure 7. Local Community Offering to Sell Land

According to a Report on the Potentialities of Karimunjawa village [22], the number of labor force aged $15-54$ was 3,044 or $59 \%$ of the total population of the village. Those who work in the field of tourism are very small in number, i.e. $10.3 \%$ of the total productive labor force (Table 3).

Table 3. People Working in Tourism

\begin{tabular}{lcc}
\hline Occupations & $\mathbf{n}$ & $\mathbf{\%}$ \\
\hline Homestay accomodation owners & 84 & 41 \\
Hotel \& Resort proprietors & 15 & 5 \\
Souvenir vendors & 22 & 6 \\
Craftmen/artisans & 15 & 4 \\
Boatmen & 32 & 8 \\
Guides and tour leaders & 146 & 36 \\
\hline Total & 314 & 100 \\
\hline
\end{tabular}

People who are actively involved in tourismrelated economic activity are mostly resident in the north and the middle of the village and along the main road. This is because the infrastructure and facilities for economic activity such as homestay accommodation, souvenir shops, and eating-places are concentrated in the northern part, i.e. the main pier for passenger ships, the village square and further to the central part of the village.

Those who get involved in tourism are mostly the youth (25-45 years old). A fisherman named AM (44) said, "older people are reluctant and hesitant to take part in tourism-related activities; furthermore, the natives of Karimunjawa are naturally diffident, and a job in tourism entails meeting strangers. Younger people are active and like this kind of employment especially that they get paid in cash directly".

The scant involvement of the people in tourism is due to the limited capabilities of human resources. An organizer of tour guides named AR (49) said, "Tour guides must have adequate qualifications. At least they should be able to use the Indonesian language well, and if they can speak fairly good English, so much the better. Besides, they must have a good communicative ability and are familiar with sapta pesona (the code of conduct for guides)".

The development of tourists' visits to Karimunjawa does not go together with the development of industries in specialty foods and handicrafts. In the past five years there have been no cottage industries, although efforts to facilitate the sales of souvenirs through kiosks/stalls and in the village square have been made. The products on sale in the funfairs and kiosks in the village square are brought in from outside Karimunjawa, i.e. from Jepara.

\section{Effects of Tourism on the Poor from the PPT Perspective}

An important part of the PPT perspective is evaluation of the effects of tourism development on poverty alleviation or elimination, not only in a theoretical framework but in the planning. However, it is not easy to see the effects of tourism development on poverty elimination because the effects cannot be directly evident or noticeable and are a gradual process. One thing worth noting is the causality of tourism and poverty elimination as distinct from the advantages of the PPT approach for tourism. 
Table 4. Opportunities and Empowerment of the Poor in Tourism-related Activities

\begin{tabular}{|c|c|c|}
\hline & $\begin{array}{c}\text { Small scale (homestay) accommodation run by } \\
\text { local community }\end{array}$ & Large scale (hotels and restaurants run by investors) \\
\hline $\begin{array}{l}\text { Opportunities } \\
\text { Earnings }\end{array}$ & $\begin{array}{l}\text { Usually below minimum wage; dependent on } \\
\text { frequency of visits; plus point: close to home }\end{array}$ & $\begin{array}{l}\text { Labor force with inadequate and qualification are paid } \\
\text { minimum wage or below; sometimes given overtime } \\
\text { pay. Employers drawn from outside the island; hence } \\
\text { migration }\end{array}$ \\
\hline $\begin{array}{l}\text { Network/ } \\
\text { economic links }\end{array}$ & $\begin{array}{l}\text { Foodstuffs, especially fish: local resources or local } \\
\text { markets. Menu: what is locally available; } \\
\text { encourage visits to nearby localities that produce } \\
\text { handicraft and refreshments, contributions to the } \\
\text { mosque; cooperation with boat, bicycle, and } \\
\text { motorcycle rentals }\end{array}$ & $\begin{array}{l}\text { Purchase foodstuffs (rice, fish, fruits etc) from big } \\
\text { suppliers from outside the island; hotels determine } \\
\text { standards of quality and security of supplies; } \\
\text { furnishings are brought in from outside Karimunjawa. } \\
\text { Local shopkeepers/vendors are allowed to sell } \\
\text { commodities around hotels }\end{array}$ \\
\hline $\begin{array}{l}\text { Opportunities } \\
\text { for progress }\end{array}$ & $\begin{array}{l}\text { Individuals are employed without formal } \\
\text { qualification }\end{array}$ & $\begin{array}{l}\text { Employees need formal qualifications, some of which } \\
\text { are offered for skills development }\end{array}$ \\
\hline $\begin{array}{l}\text { Empowerment } \\
\text { Training for } \\
\text { workers }\end{array}$ & $\begin{array}{l}\text { Owners do not provide training, only brief } \\
\text { guidelines on employees' duties }\end{array}$ & $\begin{array}{l}\text { On the job training scheme/package available for } \\
\text { employees; also for those from surrounding areas }\end{array}$ \\
\hline $\begin{array}{l}\text { Respect for } \\
\text { local tradition } \\
\text { and culture }\end{array}$ & $\begin{array}{l}\text { Help to preserve tradition and culture developed } \\
\text { through involvement in traditional events }\end{array}$ & $\begin{array}{l}\text { Help to preserve traditional and culture through } \\
\text { involvement in the promotion of traditional events }\end{array}$ \\
\hline
\end{tabular}

A number of things that should be observed from tourism in Karimunjawa from the PPT perspective are: 1). increased household earnings, albeit relatively small; 2). the emergence of diversification of means for livelihood; 3). the discrepancy/gap of the benefits of tourism between the poor and the non-poor communities, though this gap is not wide. The opportunities and empowerment of the scales of activity in tourism development are shown in the Table 4 below.

Table 4 shows a greater role of small-scale enterprises to alleviate poverty. There are more opportunities for labor force and economic network available for local community. However, the local people have little opportunity in largescale enterprises because they lack formal education and special skills.

\section{Dealing with discrepancies of capacity and skills}

Tourism development in Karimunjawa has brought economic advantage to the community. However, it is enjoyed only by small part of the population, particularly those who own assets (such as lodgings/homestay accommodation, boats for hire) and competent/capable human resources (e.g. tour leaders/tour guides). Out of $50 \%$ of the population of productive age, only $10.3 \%$ are able to contribute to the economics of tourism. The pre-welfare population in Karimunjawa is $32 \%$ with low levels of education, i.e. primary school leavers $(47.98 \%)$, primary school dropouts (32.67\%). The main obstacles of the success of PPT are the local people's limited capabilities and insufficient skills. In order to boost the benefits of tourism, increased capabilities and skills are needed as this will encourage more active participation of the locals in economic activity of tourism, which will hopefully become a strategy in poverty elimination.

In this research, six heads of poor households were invited for in-depth interview to elicit information on their willingness to alleviate poverty in their community through activities in tourism. The results of research indicate that poor households are willing to be involved in the tourism sector provided that they are given employment opportunities and earn enough to build their houses, to enhance their self-esteem, to maintain their health and ensure an increase in their income.

One of the obstacles and challenges is the high poverty figures. Poverty that is prevalent in Karimunjawa is poverty in terms of meager earnings due to the inability of people in managing and maximizing the potential of the local resources. Other contributing factors to poverty are interrelated such as insufficient availability of land both in quantity and quality, limited financial capital, inadequate access to technology, and most importantly, the low quality of human resources.

One of the efforts to eliminate poverty on the island is empowerment of the local people through vocational training. Under the existing 
condition of the majority of the people, i.e. poverty and low levels of education, one model of empowerment is vocational training oriented to the development of the informal sector, particularly tourism, which is at present a thriving industry in Karimunjawa and which the locals respond to with additional tourism-related activities.

Vocational training is only one aspect in the endeavor to improve the quality of human resources and to create job opportunities. This training should be able to develop the relevant skills needed for a supply of manpower and the growth of opportunities for new enterprises. A number of important aspects in the development of vocational education and training are as follows: 1) it should be able to fulfill the need for employment in the informal sector; 2 ) it should be able to empower people at the productive age with access to the labor market and involve them in the productive economy of tourism; 3) it should include all parties concerned in an effort to establish a link between vocational training and market demand and the business world; 4) the mechanism for the training should be designed in a sustainable way and adjusted to a situation as well as the commitment and responsibility of the stakeholders; 5) it should from part of a sustainable development strategy at regional, national, and international levels.

The most important goal of vocational training for the elimination of poverty is to empower the local community not only with basic knowledge and skills but also with a real sense of ideological commitment imbued with motivation and zeal to combat poverty.

The strategies adopted to eliminate poverty in Karimunjawa should be integrated, comprehensive, and sustainable. One strategy is the development of human resources through vocational training for tourism, which can be instituted in a Community Learning Center often called Pusat Kegiatan Belajar in the national language, i.e. Center for Learning Activity. One important feature in the strategy to empower the local community is to equip them with not only with basic knowledge and skills but with a sense of ideological commitment so that they are strongly motivated and enthusiastic to fight against poverty.

\section{CONCLUSION}

The PPT approach shows that there is a simple win-win scenario for the growth of tourism, economic development, and poverty alleviation. This article has shown that there are many examples in which the economic activity of tourism in Karimunjawa on various scales has brought direct and indirect benefits for the poor. The growth of tourism there has benefited the community economically, as evident in the increased earnings through tourism-related activities (homestay accommodation, bicycle/ pedicab, motor-cycle rentals, guides/tour leaders, souvenir artisans and vendors as well as food sellers). Opportunities for increased earnings through tourism are already available now on small and large scales. On the other hand, the poor community still cannot play a significant role in tourism. Limitations of human resources' capabilities and lack of economic assets are classic cases for the poor. Efforts to improve capabilities are expected to reduce the effects of tourism growth on the island, and to step up the poor community's participation in the economic activity of tourism, and ultimately to help them to eliminate poverty.

This research has identified a number of issues that hamper the potential for poverty alleviation in Karimunjawa. Specifically, there is a link of backwardness between tourism and economy as a whole, i.e. dependence on products from outside Karimunjawa such as foodstuffs and handicrafts. In general, the local community's participation in the tourism sector is on the increase, e.g. as employees/workers, or rental owner but very few of them are directly involved in planning and development of tourism.

\section{ACKNOWLEDGEMENT}

The Ministry of Research, Technology and Higher Education Republic Indonesia has given the grant doctor.

\section{REFERENCES}

[1] Rijanta, R. 2005. Insularitas dan keterbelakangan ekonomi wilayah menuju model konseptual perkembangan wilayah pulau-pulau kecil di Indonesia. Majalah Geografi Indonesia 19(2), 103-120.

[2] Stanford, R. J., B. Wiryawan, D. G. Bengen, R. Febriamansyah and J. Haluan. 2013. Exploring fisheries dependency and its relationship to poverty, A case study of West Sumatra, Indonesia. Ocean and Coastal Management 84, 140e152.

[3] Rashed-Un-Nabi, M., M.A. Hoque, R. A. Rahman, S. Mustafa and M.A. Kader. 2011. Poverty profiling of the estuarine set Bag 
Net fishermen community in Bangladesh. Research in World Economy 2(2), 2e20.

[4] Dien, V. V. 2009. Poverty measurement, an application for small-scale fisheries in Bich Dam Island, Vietnam. Master Thesis. University of Tromso, Norway \& Nha Trang University, Vietnam.

[5] Martin, S. M., K. Lorenzen and N. Bunnefeld. 2013. Fishing Farmers: Fishing, Livelihood Diversification and Poverty in Rural Laos. Human Ecology 41(5), 737-747.

[6] Cochrane, K., C. De Young and D. Soto (Eds). 2009. Climate change implications for fisheries and aquaculture. The Food and Agriculture Organization of The United Nations (FAO). Rome, Italy. Available at: http://www.fao.org/fileadmin/user_upload /newsroom/docs/FTP530.pdf.

[7] Johnson, J.E. and D. J. Welc. 2009. Marine fisheries management in a changing climate: a review of vulnerability and future. Fisheries Science 18(1), 106-124.

[8] UNEP. 2002. Integrated assessment of trade liberalization and trade-related policies: a country study on the fisheries sector in Argentina. UNEP. New York, USA.

[9] Lewis-cameron, A. and S. Roberts. 2010. Small island developing states: issues and prospects. In: Lewis-cameron, $\mathrm{A}$. and S. Roberts (Eds). Marketing island destinations: concepts and cases. Burlington: Elseiver/Butterworth-Heinemann, 1-8.

[10] Liew, J. 1984. Tourism and development: A re-examination in tourism in The South Pacific. In: Pearce, D. (Ed). Tourism in South Pacific: the contribution of research to development and planning. New Zealand Man and Biosphere Report No. 6. Departement of Geography, Univesity of Canterbury. New Zealand.

[11] Ashley, C. and S. Maxwell. 2001. Rethinking rural development. Development Policy Review 19(4), 395-425.

[12] Gerosa, V. 2003. Pro-poor growth strategy in Africa: tourism: a viable strategy for propoor growth in Africa? Expert Group Meeting held at Munyonyo Speke Resort Kampala, Uganda. June 23-24.

[13] Page, S., C. Ashley, D. Roe and D. Meyer. 2004. Tourism and the poor: analyzing and interpreting tourism statistics from a poverty perspective. PPT Working Paper No. 16. Pro-poor tourism partnership, UK. Available at: www.propoortourism.org.uk
[14] Torresa, R. and J. H. Momsen. 2004. Challenges and potential for linking tourism and agriculture to achieve pro-poor tourism objectives. Progress in Development Studies 4(4), 294-318.

[15] Baiquni, M., J. Damanik and E. Rindrasih. 2014. Ecotourism destinations in archipelago countries. Gadjah Mada University Press. Yogyakarta.

[16] Wilkinson, P. 1989. Strategies for tourism in the island microstates. Annals of Tourism Research 16(1), 153-177.

[17] Ashley, C., D. Roe and H. Goodwin. 2001. Pro-poor tourism strategies: making tourism work for the poor - A review of experience. Pro-Poor Tourism Report No. 1. ODI/IIED/CRT. The Russell Press. Nottingham. Available at: https://www.odi.org/ sites/odi.org.uk/files/odi-assets/publication s-opinion-files/3246.pdf.

[18] Ashe, J. W. 2005. Tourism investment as a tool for development and poverty reduction: the experience in Small Island Developing States (SIDS). The Commonwealth Finance Ministers Meeting, 18-20 September, Barbados.

[19] Ashley, C. 2000. The impacts of tourism on rural livelihoods: Namibia's experience. Working Paper 128. Sustainable Livilehood Series. Overseas Development Institute, London, UK. Available at: https://www.odi. org/sites/odi.org.uk/files/odi-assets/publica tions-opinion-files/2754.pdf.

[20] Karimunjawa National Park. 2010. Annual report of Karimunjawa National Park 2010. Office of Karimunjawa National Park. Semarang.

[21] Central Statistic Bureau. 2016. Statistic of Karimunjawa 2016. Central Statistic Bureau of Jepara. Jepara.

[22] Central Statistic Bureau. 2016. Karimunjawa Sub-district in Figures 2016. Central Statistic Bureau. Jepara.

[23] Tourism Information Center Jepara. 2014. Statistic 2014 | TIC Jepara your gateway to Jepara Tourism, Jepara, Jawa Tengah, Indonesia. Available at: http://ticjepara. com $/ ? p=513$ 